\begin{tabular}{|c|c|c|}
\hline \multirow{2}{*}{ DE } & \multirow{2}{*}{$\begin{array}{l}\text { DE GRUYTER } \\
\text { OPEN }\end{array}$} & ECONOMIC THEMES (2017) 55(1): 89-103 \\
\hline & & DOI 10.1515/ethemes-2017-0006 \\
\hline
\end{tabular}

\title{
THE INTERVENING ROLE OF COMPETITIVENESS ON THE RELATIONSHIP BETWEEN SUSTAINABILITY AND TOURISM PERFORMANCE: A RESEARCH ON EUROPEAN COUNTRIES
}

\author{
Paşa Mustafa Özyurt \\ Akdeniz University, Institute of Social Sciences, Antalya, Turkey \\ 凶ozyurt@akdeniz.edu.tr
}

\section{Kemal Kantarcı}

Alanya Alaaddin Keykubat University, Faculty of Business,Alanya, Turkey

凶kmal.kantarci@alanya.edu.tr

UDC

502.131.1:3

$38.48(4)$

Review

paper
Received: 15.07.2016. Accepted: 20.03.2017.

\begin{abstract}
Being green and being an economically successful and competitive destination has been the core topic in the sustainable development literature in recent years. The link between sustainability and competitiveness in the market is fairly important to study in the tourism industry in order to support and encourage decision makers and stakeholders in their decisions. In this sense, this study has two aims. First aim is to cluster European countries based on their sustainability scores reported in World Economic Forum's Global Competitiveness Index. Second aim is to reveal the intervening role of competitiveness on the relationship between sustainability and tourism performance for European countries. We employed a K-means cluster analysis and several multiple regression analyses. Analyses results revealed three clusters for European countries. Another finding postulated that competitiveness of these countries have been influenced by their level of sustainability. Our final finding posits that tourism performance of these countries in terms of tourist arrivals and tourism receipts has been found to be impacted by the level of tourism competitiveness.
\end{abstract}

Keywords: sustainability, tourism competitiveness, global competitiveness, tourism performance, European countries.

JEL classification: Z32, M21 


\section{Introduction}

The tourism industry has been playing an important role for governments, destinations, businesses and stakeholders by means of its economic, social and environmental impacts.There is a strong competition in the marketplace in order to benefit more from its economic valuesince it supports job creation, investments and foreign exchange earnings. The number of international tourist arrivals have been increasing continuously since 1950s and reached a total of 1,186 million in 2015 and is expected to grow over the next years and hit 1.8 billion by 2030 . Accordingly, international tourism receipts have also been increasing and reached US\$ 1,260 billion in 2015 which represent 7\% of world's exports in good and service (World Tourism Organization, [WTO] 2016, p. 2). All these growing numbers are a proof of rising competitions among tourism destinations worldwide. And also, the importance of economic contribution of tourism continuously commands the creation of policies and incentives that support tourism development and benefit from it more, especially in emerging markets (Budeanu, 2005, p. 89). The success of a destination in tourism market depends on some factors. These factors can be different from each other depending on the destination's characteristics, resources and other conditions. In this point, sustainability and competitiveness are the two crucial notionsthatshould be considered by governments and destinations to strength their position, to increasetheir tourism revenues and to reach their long-term objectives. High level of sustainability contributes to competitiveness of countries and consequently helps them to benefit more from tourism industry in terms of its economic contributions. By the similar vein, sustainability has a critical role for tourism destinations in order to achieve their economic, social and environmental goals. In this sense, destinations strive to increase their competitiveness level by developing a sustainable environment, economic, and social climate to be able to increase economic development level.

The aim of this study is to investigate the intervening role of competitiveness on the relationship between sustainability and tourism performance of European countries. Europe is the continent where international tourism movements occurs the most around the world. According to WTO (2016, p. 2) it is the most visited region in 2015 with the 608 million international tourists arrivals. For the same year, tourism revenue reached US\$ 541 billion throughout the continent. Furthermore, Europe region has some of the most visited countries in the world such as France, Spain, Italy, Turkey and United Kingdom. In addition to this, it should also be stated that some countries in the region are not really popular as a tourism destination. Therefore, in this study it was aimed to find out if there is a significant relationship between sustainability and tourism performance of the countries by means of international tourist numbers and tourism revenues and also to determine whether the competitiveness has a meaningful effect on this relationship or not. 


\section{Theoretical Framework}

What makes a destination to be successful and popular or what are the core determinants of being a successful destination has been one of the main research topics in tourism area. For some researchers (Hassan, 2000, p. 242; Dwyer and Kim, 2003, p. 397) safety, security and providing high level of health care facilities are the most important determinants in order to be a popular tourism destination. Some others (Bornhorst, et.al., 2010, p. 587) indicated the importance of product and service offerings in the destination, location and accessibility and community support. While Buhalis (2000, p. 113)stated the partnership and close relations between all stakeholders of the destination is the key factor to provide quality products to visitors and reach long term objectives of the destination, Gunn and Var (2002, p. 41) mentioned attractions, promotion, tourism infrastructure and services as the essential drivers. Prideaux (2000, p. 61) investigated the relations between accessibility and tourism development and concluded that type of transport infrastructure in a destination is an important determinant. Ritchie and Crouch (2000, p. 5) stressed the importance of sustainability and competitiveness of a destination as the main determinants of the success. In this point, sustainability and competitiveness should be identified as the distinctive and leader factors among all of these determinants.

Sustainability has been in the middle of attention since the announcement of the Our Common Future, known as Brundtland Report, in 1987 by World Commission on Environment and Development. In the report, sustainable development is defined as a process to meet the needs of the present without compromising the ability of future generations to meet their own needs. Sustainable development requires the cooperation of all stakeholders and aims to enhance the quality of life of people as well as the social and natural environment (Ko, 2005, p. 443).Sustainability has three different dimensions which are economic, environmental and social sustainability. Economic sustainability addresses the cost effectiveness of all economic activity and fair distribution of income. Social sustainability means equal opportunities for all in society. It requires an equitable distribution of benefits. Environmental sustainability requires action to minimise any kind of pollution and to conserve biological diversity and natural heritage in the destination. The main aim of the sustainability is to increase and strengthen the positive impacts of tourism and prevent and reduce the negative ones. Sustainability in the tourism industry has twelve different targets, as follows (UNEP, 2005, pp. 9, 18):

- Economic Viability: To ensure the viability and competitiveness of tourism destinations and enterprises, in order to support their long-term success.

- Local Prosperity: To maximise the contribution of tourism to the economic prosperity of the host destination, including the proportion of visitor spending that is retained locally. 
- Employment Quality: To strengthen the number and quality of local jobs created and supported by tourism, including the level of pay conditions of service and availability to all without discrimination by gender, race, disability or in other ways.

- Social Equity: To seek a widespread and fair distribution of economic and social benefits from tourism throughout the recipient community, including improving opportunities, income and services available to the poor.

- Visitor Fulfilment: To provide a safe, satisfying and fulfilling experience for visitors, available to all without discrimination by gender, race and disability or in other ways.

- Local Control: To engage and empower local communities in planning and decision making about the management and future development of tourism in their area, in consultation with other stakeholders.

- Community Wellbeing: To maintain and strengthen the quality of life in local communities, including social structures and access to resources, amenities and life support systems, avoiding any form of social degradation or exploitation.

- Cultural Richness: To respect and enhance the historic heritage, authentic culture, traditions and distinctiveness of host communities.

- Physical Integrity: To maintain and enhance the quality of landscapes, both urban and rural, and avoid the physical and visual degradation of the environment. 1

- Biological Diversity: To support the conservation of natural areas, habitats and wildlife, and minimise damage.

- Resource Efficiency: To encourage the use of renewable energy in tourism based businesses.

- Environmental Purity: To minimise the pollution of air, water and land and the generation of waste by tourism enterprises and visitors.

Sustainability and sustainable tourism have been one of the most studied and debated (Garrod and Fyall 1998; Butler, 1999; Tosun, 2001; Buckley, 2012; Weaver, 2012; Moscardo, 2016) issues in tourism field. In tourism sustainability field, development of an objective assessment methodology is crucial. This method is important for the sustainability of the idea of sustainable development and also for realisation of major contemporary objectives in the tourism industry. Thus, industry and its components can measure their performance and impacts in this area (Ko, 2005, p. 432). In addition to that, being environmentally responsible and economically successful and competitive destination have been main topic in the sustainable tourism development literature (Cohen et al., 1995; Hassan, 2000; Mihalic, 2000; Hu and Wall, 2005; Rodriguez and Cruz, 2007; Leonidou, et.al.,2013). Some researchers argued that, improved environmental performance largely causes extra cost for the destination and reduces profits. However, the opposite point of view focuses on improved environmental performance would 
induce cost savings and increase sales and thus improve revenues. Debates in theoretical and empirical researches for both positions have not been conclusive so far. One of the reasons of this results maybe to use different data set in the empirical studies. Another reason for the contradictory results may be lack of agreement of a common theoretical framework. It should also be considered that destinations have their unique environment and conditions so they differ from each other. Thus, it might be another determinant to find inconsistent results (Schaltegger and Synnestvedt, 2002, p. 340).

The success of a destination in the world market depends on its competitiveness (Enright and Newtown, 2004, p. 777; Cracolici and Nijkamp, 2008, p. 336). Dwyer and Kim (2003, p. 380) emphasise that the ultimate goal of a destination's competitiveness is to increase socioeconomic wellbeing of its citizens and provide them better living conditions. According to Porter (1990, p. 77) competitiveness has four different determinants as factor conditions, demand conditions, related and supporting industries and firm strategy, structure and rivalry. Factor conditions consist of any kind of factors of productions, such as skilled labour, infrastructure and business conditions. Demand conditions are the nature of the home market. Related and supporting industries are the presence or absence of the national or international supplier industries. Firm strategy, structure and rivalry define the conditions that how companies are created, organized and managed. Considering Porter's diamond model, Crouch and Ritchie (1999, p. 146) postulate that competitiveness in tourism destinations is determined by four main components as; (i) core resources and attractors which consist of core tourist products such as beaches, natural attractions, culture, historical buildings and etc.,(ii) supporting factors and resources which include infrastructure, accessibility, enterprises and so on,(iii) destination management which consist any kind of management in the destination such as organizations, marketing, etc., and (iv) qualifying determinants consist of location, image, safety and security of the destination. They have also stated the importance of understanding competitive and comparative advantage in order to better comprehend competitiveness in tourism destinations. Comparative advantage consists of any kind of natural and man-made resources in a destination which involves natural, historical and cultural attractions, tourism infrastructure and location advantages. These are the main resources which give an advantage to a destination comparing its rivals. But having a great comparative advantage does not necessarily mean having competitive advantage as well. Competitive advantage is about to use its resources effectively over the longterm. At this point, it can be said that competitiveness in a tourism destination depends on cooperation among stakeholders and their visions, values and expectations, understanding the destination's strength and weaknesses, effectively use of its resources in order to strengthen its position in the marketplace and to improve its human resources and tourism infrastructure. 
Dwyer and Kim (2003, p. 373) stated the need of a developing specifically tourism based competitiveness model in order to better understand and identify key success factors in tourism destinations, since there are significance differences between the nature of tourism products and traditional products. According to the authors, determinants of destination competitiveness are as follows: Resources, situational conditions, destination management, and demand conditions. Resources consist of two different types as natural and created. Natural resources include natural environment such as lakes, mountains, beaches, rivers, climate, etc. and cultural resources include any kind of cultural heritage such as cuisine, language, handicrafts, customs, belief system etc. Created resources include tourism infrastructure, special events, shopping and entertainment. In addition to these two resources, there is the third one, supporting resources which include general infrastructure, accessibility, services quality, hospitality, and market ties. Situational conditions are about wider environment that may have negative or positive impact upon destination such as economy, politics, culture, environment, technology, events, demographics etc. Destination management consists of planning and organising any kind of activities by public and private sector. It includes activities of destination management organisations, destination marketing management, destination policy, planning, and development, human resources development and environmental management, tourism industry association, industry training programmes and so on. Demand conditions involve three elements as a tourism demand awareness, perception and preferences. Actual visitation depends on the match between preferences and perceived destination products. According to the authors, the ultimate aim of destination competitiveness is to be a mediator to enhance the well-being of residents in the destination.

Hassan (2000, p. 240) has defined the competitiveness in tourism sector as the destination's ability to create and integrate value-added products that sustain its resources while maintaining market position relative to competitors. He also stated that the long-term success of a destination depends on its ability to turn its comparative advantages into sustainable competitive advantages. Competitiveness should be supported by sustainability in order to obtain long-term targets. For this purpose, it is necessary to define the strengths and weaknesses of the destination and to position it in the best possible manner. Competitive strategy is the search for a favourable competition position in an industry, the fundamental arena in which competition occurs. Competitive strategy aims to establish a profitable and sustainable position against to forces determines industry competition (Porter, 2008, p.3; Develioğlu and Kantarci, 2012, p. 240).

Crouch (2010) has conducted a research in order to determine the most important attributes which affect the destination competitiveness. The findings indicate that physiography and climate, mix of activities, culture and history, tourism superstructure, safety and security, cost and value, accessibility and special events have been found the most influential determinants of destination 
competitiveness. The study carried out by Chin et. al., (2014) supported the idea that natural resources and cultural heritage are the two important determinants of competitiveness in a destination. An interesting result has been found out by Webster and Ivanov (2014) that there were no direct positive and statistically meaningful relationship between a destination's competitiveness and economic contribution of tourism. It was obtained from the findings that tourism contributes to economic growth more in less competitive destinations. The finding of Cucculelli and Goffi's study (2016) is an important example for the relations between sustainability and competitiveness. Study results reveal that sustainable tourism development is not only good for preserving the ecologic balance of a tourism destination, but also for improving its competitiveness. The study results of Cracolici and Nijkamp (2008) is shown that as a tourist destination, having natural and cultural resources represent only a comparative advantage but not sufficient conditions to be competitive.

\section{Research framework}

This study has two main aims: The first is to cluster European countries by using their sustainability scores reported in World Economic Forum's Global Competitiveness Index. The second aim of this study concerns with investigation of the intervening role of competitiveness on the relationship between sustainability and tourism performance of European countries. In order to state above mentioned relationships, theoretical framework of the study will be presented in the following part of this study.

Figure 1. Model of the Study: The Intervening Role of Competitiveness on the Relationship between Sustainability and Tourism Performance

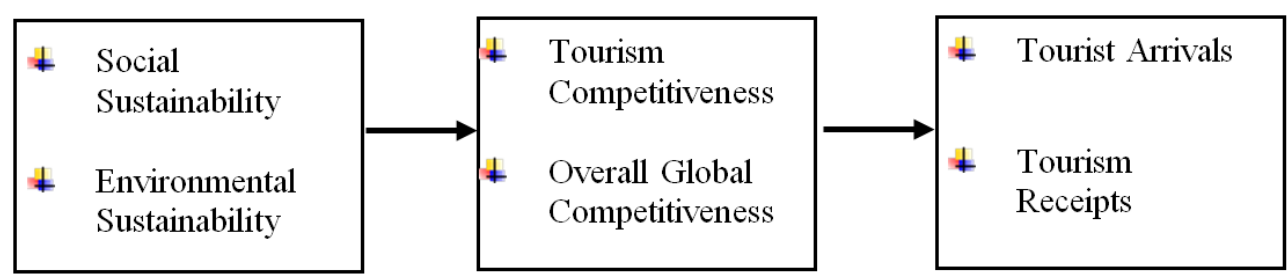

\section{Hypothesis of the study are:}

$\mathbf{H}_{1}$ : Social and environmental sustainability level of European countries will have a positive impact on their tourism competitiveness.

$\mathbf{H}_{2}$ : Social and environmental sustainability level of European countries will have a positive impact on their overall global competitiveness.

$\mathbf{H}_{3}$ : Competitiveness level of European countries will have a positive impact on their performance in terms of tourist arrivals. 
$\mathbf{H}_{\mathbf{4}}$ : Competitiveness level of European countries will have a positive impact on their performance in terms of tourism receipts.

\section{Methodology and Findings}

In this study, we used the data of The World Economic Forum's (WEF) "Global Competitiveness Index" and "Travel Tourism Competitiveness Index" for the years 2011-2013 and also we obtained the tourism numbers (tourism income and tourist numbers) from United Nations database (UNdata, 2016).In order to cluster European countries in terms of social and environmental sustainability variables, we employed a k-means cluster analysis and derived three clusters, which is reported in Table 1 below. One of these clusters (Cluster 1) includes countries: Armenia, Bulgaria, Croatia, Cyprus, Greece, Hungary, Italy, Macedonia, Moldovia, Poland, Portugal, Romania, Russia, Serbia, Slovakia, Turkey, and Ukraine. The second cluster (Cluster 2) countries are Austria, Belgium, Finland, Germany, Netherland, Norway, Sweden, Switzerland, and United Kingdom. The third cluster (Cluster 3) includes nine countries, which are Czech Republic, Denmark, Estonia, France, Ireland, Latvia, Lithuania, Slovenia, and Spain.

Table 1: Cluster Membership by Country

\begin{tabular}{lll}
\hline Cluster 1 & Cluster 2 & Cluster3 \\
\hline Armenia & Austria & Czech Republic \\
Bulgaria & Belgium & Denmark \\
Croatia & Finland & Estonia \\
Cyprus & Germany & France \\
Greece & Netherland & Ireland \\
Hungary & Norway & Latvia \\
Italy & Sweden & Lithuania \\
Macedonia & Switzerland & Slovenia \\
Moldovia & United Kingdom & Spain \\
Poland & & \\
Portugal & & \\
Romania & & \\
Russia & & \\
Serbia & & \\
Slovakia & & \\
Turkey & & \\
Ukraine & & \\
\hline
\end{tabular}

Source: Authors' caclulation

For the purpose of testing our model presented above, we employed fourmultiple regression analyses. In the first regression analysis, we aimed to test the impact of two independent variables, social and environmental sustainability, on dependent variable, tourism competitiveness. Analysis results, which are portrayed 
in Table 2, posit that the model is significant $(F=70,099 ; \mathrm{p}=0,000)$ and one of the independent variables, namely social sustainability (Beta $=0,825 ; \mathrm{p}=0,000)$, has a significant explanatory power $\left(R^{2}=0.68\right)$ for the variance in our dependent variable, tourism competitiveness. Thus, our first hypothesis found partial support from analysis conducted.

Table 2. Regression analysis results for sustainability and tourism competitiveness

\begin{tabular}{|l|c|c|}
\hline Independent Variables & Beta & Significance of $t$ \\
\hline Social Sustainability & 0,825 & 0,000 \\
Environmental Sustainability & 0,252 & 0,255 \\
\hline $\mathrm{R}^{2}$ & $\mathrm{~F}$ & Significance of $\mathrm{F}$ \\
\hline 0.68 & 70,099 & 0,000 \\
\hline
\end{tabular}

*Dependent variable: Tourism Competitiveness

Source: Authors' caclulation

In order to test the impact of sustainability performance of countries on their overall global competitiveness positions, we employed another multiple regression analysis, which is reported in Table 3. Analysis results in Table 3 revealed the fact that, similar to previous analysis results, in explaining the variance in overall competitiveness positions $\left(R^{2}=0.97 ; F=1076,881 ; p=0,000\right)$ of countries, social sustainability (Beta $=0,985 ; \mathrm{p}=0,000$ ) can be used as an explanatory variable. Based on analysis results, hypothesis 2 can be partially accepted.

Table 3. Regression analysis results for sustainability and overall global competitiveness

\begin{tabular}{|l|c|c|}
\hline Independent Variables & Beta & Significance of $t$ \\
\hline Social Sustainability & 0,985 & 0,000 \\
Environmental Sustainability & 0,063 & 0,350 \\
\hline $\mathrm{R}^{2}$ & $\mathrm{~F}$ & Significance of $\mathrm{F}$ \\
\hline 0.97 & 1076,881 & 0,000 \\
\hline
\end{tabular}

*Dependent variable: Overall Global Competitiveness

Source: Authors' caclulation

In this study, the third multiple regression analysis aimed to reveal the impact of competitiveness on tourism performance, namely number of tourist arrivals. In order to test this, we used two competitiveness, namely, tourism competitiveness and overall global competitiveness, variables as independent and tourist arrivals as dependent variable, Analysis results, which are shown in Table 4, revealed that one 
of our independent variables, tourism competitiveness (Beta: 0,403: $p=0,016$ ), has a statistically significant $\left(\mathrm{R}^{2}=0.16 ; \mathrm{F}=6,392 ; \mathrm{p}=0,016\right)$ impact on tourist arrivals in European countries. Thus, we can conclude that hypothesis 3 found a partial support from analysis conducted.

Table 4. Regression analysis results for competitiveness and tourist arrivals

\begin{tabular}{|l|c|c|}
\hline Independent Variables & Beta & Significance of $t$ \\
\hline Tourism Competitiveness & $\begin{array}{c}0,403 \\
-0,415\end{array}$ & 0,016 \\
Overall Global Competitiveness & $\mathrm{F}$ & Significance of F \\
\hline $\mathrm{R}^{2}$ & 6,392 & 0,016 \\
\hline 0.16 & \\
\hline
\end{tabular}

*Dependent variable: Tourist Arrivals

Source: Authors' caclulation

In order to test our fourth hypothesis, we run another multiple regression analysis and found that (see Table 5) tourism receipts of European countries has been impacted by one of the competitiveness variables, namely, tourism competitiveness (Beta: 0,598: $\mathrm{p}=0,000)$. The model is significant $(\mathrm{F}=18,371 ; \mathrm{p}=$ 0,000 ) and tourism competitiveness variable, alone, explains 36 percent of variance in dependent variable, tourism receipts. Based on analysis results, hypothesis 4 found a partial support and can be accepted.

Table 5. Regression analysis results for competitiveness and tourism receipts

\begin{tabular}{|l|c|c|}
\hline Independent Variables & Beta & Significance of $t$ \\
\hline Tourism Competitiveness & $\begin{array}{c}0,598 \\
-0,304\end{array}$ & $\begin{array}{c}0,000 \\
0,225\end{array}$ \\
\hline Overall Global Competitiveness & $\mathrm{F}$ & Significance of F \\
\hline $\mathrm{R}^{2}$ & 18,371 & 0,000 \\
\hline 0.36 & & 0 \\
\hline
\end{tabular}

*Dependent variable: Tourism Receipts

Source: Authors' caclulation

In order to compare clustered European countries based on their sustainability scores, we run a One Way ANOVA analysis and obtained the results, which are reported in Table 6. Scores in Table 6 betray that Cluster 2 countries have highest sustainability scores compared to Cluster 1 and Cluster 3 countries. Specifically, a statistically significant difference $(F=98,834 ; p=0,000)$ has been detected for social sustainability scores of Cluster 1 (Mean= 4.10), Cluster 2 (Mean=6.29) and Cluster 3 (Mean= 5.04) countries. Similarly, we found similar results for environmental sustainability variable, namely, Cluster 1 (Mean= 4.04), Cluster 2 
(Mean= 6.04) and Cluster 3 (Mean= 4.75) countries displayed statistically significant environmental sustainability scores $(F=84,337 ; p=0,000)$. The results postulates that sustainability scores of Cluster 2 countries are higher compared to Cluster 3 and Cluster 1 countries.

Table 6. ANOVA Analysis Results for Cluster Membership and Type of Sustainability

\begin{tabular}{|c|c|c|c|c|c|}
\hline \multirow{2}{*}{ Type of Sustainability } & \multicolumn{3}{|c|}{ Cluster } & \multirow{2}{*}{$\mathbf{F}$} & \multirow{2}{*}{$\mathbf{p}$} \\
\hline & 1 & 2 & 3 & & \\
\hline Social Sustainability & 4.10 & 6.29 & 5.04 & 98,834 & 0,000 \\
\hline Environmental Sustainability & 4.04 & 6.04 & 4.75 & 84,337 & 0,000 \\
\hline
\end{tabular}

Source: Authors' caclulation

For the purpose of comparing clustered three groups of countries based on their competitiveness scores, we run a second One Way ANOVA analysis. Results (see Table 7) portrayed that, similar to their performance for sustainability scores, Cluster 2 countries performed better in terms of both tourism and overall global competitiveness performance compared to Cluster 1 and 2 countries. Specifically, a statistically significant difference $(\mathrm{F}=19,712 ; \mathrm{p}=0,000)$ has been detected for tourism competitiveness scores of Cluster $1($ Mean= 4.34), Cluster $2($ Mean= 5.25) and Cluster 3 (Mean= 4.85) countries. Similarly, we found similar results for overall global competitiveness variable, namely, Cluster 1 (Mean=4.17), Cluster 2 $($ Mean $=5.41)$ and Cluster 3 (Mean= 4.66) countries displayed statistically significant overall global competitiveness scores $(F=82,787 ; p=0,000)$. The results postulate that sustainability score of Cluster 2 countries is higher compared to Cluster 3 and Cluster 1 countries. ANOVA analysis results for sustainability and competitiveness support each other that cluster, which is scored higher in sustainability variable will also have a higher score in competitiveness. It is useful to remind reader that we did not run another ANOVA analysis for tourism performance (tourist arrivals and tourism receipts) because in the same cluster countries highly varied in their performance and it would make the results discussing.

Table 7. ANOVA Analysis Results for Cluster Membership and Type of Competitiveness

\begin{tabular}{|c|c|c|c|c|c|}
\hline \multirow{2}{*}{ Type of Competitiveness } & \multicolumn{3}{|c|}{ Cluster } & \multirow{2}{*}{$\mathbf{F}$} & \multirow{2}{*}{$\mathbf{p}$} \\
\hline & 1 & 2 & 3 & & \\
\hline Tourism Competitiveness & 4.34 & 5.25 & 4.85 & 19,712 & 0,000 \\
\hline Overall Global Competitiveness & 4.17 & 5.41 & 4.66 & 82,787 & 0,000 \\
\hline
\end{tabular}

Source: Authors' caclulation 


\section{Conclusion}

Tourism is an increasingly competitive and sensitive to risks and uncertainties sector. Resources (natural, cultural, man-made) used in tourism are fairly delicate and easily perishable character. To define common quality standards provides a framework to guide stakeholders in the tourism industry to improve their operations and services along the whole tourism value chain in order to create a positive and completed tourism experience. In fact, sustainable tourism process is significantly a quality standard and quality management indicators and process which are key tools for the competitiveness of tourism destinations. Therefore, promoting the use of sustainable tourism indicators for measurement since the early 1990s has been an essential instrument for effective tourism policy planning and management at destinations. These approaches have increased the perspectives to better understand destination-wide resource use and foster the sustainable management of tourism. Stakeholders in the sustainable tourism process in a certain destination stressed the need for more evidence-based decision making to focus and invest in sustainable tourism projects to support at the local level. One of these key evidences is correlation and regression between sustainable tourism indicators and tourism performance indicators for measurement that how sustainability profitable and competitive way are to achieve. This study focused on the links between the sustainable tourism and tourism performance indicators.

Analysis results in findings section of this study revealed that European countries can be clustered in three groups based on their level of sustainability scores. Analysis of differences among clusters revealed some meaningful insights. One of them is that Cluster 2 countries scored higher in both sustainability and competitiveness scores compared to Cluster 1 and Cluster 3 countries. This result is important because it posits that sustainable countries will have a better competitive score and, perhaps, will perform better tourism performance. To be able to state this notion on a more stable ground, we conducted further analysis, four-multiple regression analyses. Results revealed facts that sustainability of countries has a significant impact on their competitiveness and as a result their level of tourism performance. In this sense, we can propose policy makers at governmental and firm level that tourism performance is highly dependent on level of competitiveness at national level. It can also be postulated from our results that tourism performance of countries is dependent on their level of sustainability. Policy makers, especially in national level, should strive for the ways to increase their countries level of, both, social sustainability and environmental sustainability in order to acquire a higher tourism performance. 


\section{References}

Bornhorst, T., Ritchie, J.R. and Sheehan, L. (2010). Determinants of Tourism Success for DMOs and Destinations: An Empirical Examination of Stakeholders' Perspective. Tourism Management, 31, 572-589.

Buckley, R. (2012). Sustainable Tourism: Research and Reality. Annals of Tourism Research, 39(2), 528-546.

Budeanu, A. (2005). Impacts and Responsibilities for Sustainable Tourism: A Tour Operator's Perspective. Journal of Cleaner Production, 13, 89-97.

Buhalis, D. (2000). Marketing the Competitive Destination of the Future. Tourism Management, 21, 97-116.

Butler, R. W. (1999). Sustainable Tourism: A State-of-the-art Review. Tourism Geographies, 1(1), 7-25.

Chin, C. H., Lo, M. C., Songan, P. and Nair, V. (2014). Rural Tourism Destination Competitiveness: A Study on Annah Rais Longhouse Homestay, Sarawak, Procedia- Social and Behavioural Sciences, 144, 35-44.

Cohen, M. A., Fenn, S., and Naimon, J. S. (1995). Environmental and Financial Performance: Are They Related?,Investor Responsibility Research Center, Environmental Information Service. Working Paper, Owen Graduate School of Management, Vanderbilt University, Nashville. TN.

Cracolici, M. F. and Nijkamp, P. (2008). The Attractiveness and Competitiveness of Tourist Destinations: A Study of Southern Italian Regions. Tourism Management. 30, 336-344.

Crouch, G. I. (2010). Destination Competitiveness: An Analysis of Determinant Attributes. Journal of Travel Research. 1-19.

Crouch, G. I. and Ritchie, J. R. (1999). Tourism, Competitiveness and Social Prosperity. Journal of Business Research. 44, 137-152.

Cucculelli, M. and Goffi, G. (2016). Does Sustainability Enhance Tourism Destination Competitiveness? Evidence From Italian Destination of Excellence. Journal of Cleaner Production. 111, 370-382.

Develioğlu, K., and Kantarci, K., (2012). Clustering Balkan Countries Based on Competitiveness Factors: A Strategic Perspective. Journal of Economic and Social Studies, 2(2). 237-244.

Dwyer, L., and Kim, C. (2003). Destination Competitiveness: Determinants and Indicators. Current Issues in Tourism, 6(5), 369-414.

Enright, M. J. and Newton, J. (2004). Tourism destination Competitiveness: A Quantitative Approach. Tourism Management, 25, 777-788.

Garrod, B., and Fyall, A. (1998). Beyond the Rhetoric of Sustainable Tourism?, Tourism Management, 19(3), 199-212.

Gunn, C. A., and Var, T. (2002). Tourism Planning: Basics, Concepts, Cases. Routledge, New York.

Hassan, S. S. (2000). Determinants of Market Competitiveness in an Environmentally Sustainable Tourism Industry. Journal of Travel Research, 38(3), 239-245.

$\mathrm{Hu}, \mathrm{W}$., and Wall, G. (2005). Environmental Management, Environmental Image and the Competitive Tourist Attraction. Journal of Sustainable Tourism, 13(6), 617-635.

Ko, T. G. (2005). Development of a Tourism Sustainability Assessment Procedure: a Conceptual Approach. Tourism Management, 26(3), 431-445. 
Leonidou, L. C., Leonidou, C. N., Fotiadis, T. A., and Zeriti, A. (2013). Resources and Capabilities as Drivers of Hotel Environmental Marketing Strategy: Implications for Competitive Advantage and Performance. Tourism Management, 35, 94-110.

Mihalič, T. (2000). Environmental Management of a Tourist Destination: A factor of Tourism Competitiveness. Tourism Management, 21(1), 65-78.

Moscardo, G. (2016). Building Excellence in Sustainable Tourism: 15 years of Building Excellence in Sustainable Tourism Education Network (BEST EN) practice. Journal of Cleaner Production, 111, 538-539.

Porter, M. E. (1990). The Competitive Advantage of Notions. Harvard Business Review, 68(2), 73-93.

Porter, M. E. (2008). On Competition. Boston: Harvard Business Press.

Prideaux, B. (2000). The Role of the Transport System in Destination Development. Tourism Management, 21(1), 53-63.

Ritchie, J. B and Crouch, G. I. (2000). The Competitive Destination: A Sustainability Perspective. Tourism Management, 21(1), 1-7.

Rodríguez, F. J. G., and Cruz, Y. M. A. (2007). Relation Between Social-Environmental Responsibility and Performance in Hotel Firms. International Journal of Hospitality Management, 26(4), 824-839.

Schaltegger, S., and Synnestvedt, T. (2002). The Link Between 'Green' and Economic Success: Environmental Management as the Crucial Trigger Between Environmental and Economic Performance. Journal of Environmental Management, 65(4), 339-346.

Tosun, C. (2001). Challenges of Sustainable Tourism Development in the Developing World: The Case of Turkey. Tourism Management, 22(3), 289-303.

United Nations Environment Programme (UNEP) (2005) Making Tourism More Sustainable, A Guide for Policy Makers. Paris, France.

World Tourism Organization (2016). Tourism Highlights 2016 Edition.Retrieved from: http://www.e-unwto.org/doi/book/10.18111/9789284418145

United Nations (2016). http://data.un.org/DocumentData.aspx?id=375 (1.05.2016)

Weaver, D. B. (2012). Organic, Incremental and Induced Paths to Sustainable Mass Tourism Convergence. Tourism Management, 33(5), 1030-1037.

Webster, C. and Ivanov, S. (2014). Transforming Competitiveness into Economic Benefits: Does Tourism Stimulate Economic Growth in More Competitive Destinations?,Tourism Management, 40, 137-140.

World Economic Forum (WEF). (2011). Global Competitiveness Index 2011.

World Economic Forum (WEF). (2013). Global Competitiveness Index 2013.

World Economic Forum, (2011). Travel \& Tourism Competitiveness Report, 2011.

World Economic Forum, (2013). Travel \& Tourism Competitiveness Report, 2013.

\section{INTERVENTNA ULOGA KONKURENTNOSTI NA ODNOS IZMEĐU ODRŽIVOSTI I PERFORMANSI TURIZMA: ISTRAŽIVANJE NA PRIMERU ZEMALJA EVROPE}

Apstrakt: Biti „zelena“ i biti ekonomski uspešna i konkurentna destinacija bila je značajna tema u literaturi o održivom razvoju u poslednjih nekoliko godina. Veza između održivosti i konkurentnosti na tržištu je prilično važna za 
proučavanje $\mathrm{u}$ turističkoj industriji $\mathrm{u}$ cilju podrške i podsticanja donosilaca odluka i stejkholdera u svojim odlukama.U tom smislu, ova studija ima dva cilja. Prvi cilj je da povežemo evropske zemlje na osnovu njihovih rezultata održivosti zabeleženih u Globalnom indeksu konkurentnosti Svetskog ekonomskog foruma. Drugi cilj je da se otkrije interventna uloga konkurentnosti na odnos između održivosti i performansi turizma za evropske zemlje. Iskoristili smo analizu K-sredina klaster i nekoliko višestrukih regresionih analiza. Rezultati analize su otkrili tri klastera za evropske zemlje. Drugi nalazi su utvrdili da je konkurentnost tih zemalja pod uticajem njihovog nivoa održivosti. Naš krajnji zaključak pretpostavlja da su performanse turizma ovih zemalja u pogledu broja turista i prihoda turizma pod uticajem nivoa konkurentnosti turizma.

Ključne reči: održivost, konkurentnosti turizma, globalna konkurentnost, performanse turizma, evropske zemalje

\section{Authors' biographies}

Kemal Kantarci is a full professor at the Faculty of Business, Department of Tourism Management, Alanya Alaaddin Keykubat University, Turkey.He conducted researches at the Virginia Polytechnic University during 2006. He is currently working as a visitor professor at the North Caroline University, funded by TUBITAK (the Scientific and Technological Research Council of Turkey). He has been teaching tourism related subjects at the bachelor, master and doctoral level. His research interests include tourism policy and planning, tourism marketing, movie induced tourism and tourism geography. He is also interested in regional studies regarding Silk Road Countries, Central Asia and Balkan Countries. He has published several research papers, books and and book chapters.

Paşa Mustafa Özyurt is a Ph.D candidate at the Social Sciences Institute, Department of Tourism Management, Akdeniz University, Turkey.Also, He hasbeen working at the same university as a researcher. He has spent some time in several universities in Spain, Serbia, and Lithuania for his education. The major fields of his research topics include quality of life and tourism studies, tourism geography, sustainable tourism and tourism and cultural studies. 